\title{
Behavior of composite self-compacting concrete (SCC) reinforced with steel wires from waste tires
}

\section{Comportamiento del hormigón compuesto autocompactante (SCC) reforzado con cables de acero de llantas de desecho}

Mehmet Alpaslan Köroğlu (Main and Corresponding Author) Faculty of Engineering and Architecture, Necmettin Erbakan University 42090 Meram, Konya (Turkey)

makoroglu@konya.edu.tr

Manuscript Code: 1108

Date of Acceptance/Reception: 03.12.2018/16.04.2018

DOI: $10.7764 /$ RDLC.17.3.484

\begin{abstract}
Large amount of waste tires are generated progressively every year. Therefore, many researches have been conducted on using recycled tire products in several civil engineering products. This paper is focusing on feasibility of using recycled steel fibers from waste tires as reinforcement in functionally graded self-compacting concrete (SCC). Firstly, fresh and hardened properties of the normal and steel fiber reinforced concretes were investigated. After obtaining the mechanical properties of steel fiber reinforced SCC, 16 multi-layered beams were tested under 4 point bending test by considering various fiber fractions and layer thickness. Additionally, SEM images were used to maintain the failure mechanisms between steel fibers and concrete matrix.
\end{abstract}

Key words: Waste tire, recycled steel, steel wires, self-compacting concrete.

Resumen

Gran cantidad de llantas de desecho se generan progresivamente cada año. Por lo tanto, se han realizado muchas investigaciones sobre el uso de productos de neumáticos reciclados en varios productos de ingeniería civil. Este documento se centra en la viabilidad de utilizar fibras de acero recicladas de llantas de desecho como refuerzo en concreto autocompactante graduado funcionalmente (SCC). En primer lugar, se investigaron las propiedades frescas y endurecidas de los hormigones normales y reforzados con fibra de acero. Después de obtener las propiedades mecánicas del SCC reforzado con fibra de acero, se probaron 16 vigas de múltiples capas en una prueba de flexión de 4 puntos considerando varias fracciones de fibra y espesor de capa. Además, se utilizaron imágenes SEM para mantener los mecanismos de falla entre las fibras de acero y la matriz de concreto.

Fibers have been used for reinforcing various construction materials since ancient times. Concrete, one of the most consume material in construction industry, has been researched in order to improve its mechanical properties (Köken, Köroğlu, \& Yonar, 2008). Fiber Reinforced Concrete (FRC) behaves mechanically different from conventional concrete (Köroglu \& Özdöner, 2016). FRC generally includes steel fiber (Lerch, Bester, Van Rooyen, Combrinck, Villiers \& Boshoff, 2018), natural fibers (Bharath \& Basavarajappa, 2016; Wei \& Meyer, 2015), synthetic fibers (Amin, Foster, Gilbert, \& Kaufmann, 2017; Lerch et al., 2018; Macanovskis, Krasnikovs, Kononova, \& Lukasenoks, 2017; Richardson \& Ovington, 2017; Zhang \& Li, 2012) and glass fibers (Tassew \& Lubell, 2014). A Great number of experimental studies have been conducted (Köksal, Gencel, Unal, \& Durgun Muhammed, 2012; Lee, Yi, \& Oh, 2008; Li, Li, Shi, \& Zhou, 2017; Liu, Lu, Wang, \& Liang, 2017; Macanovskis et al., 2017; C. S. Poon, Shui, \& Lam, 2004; Tassew \& Lubell, 2014; Varona, Baeza, Bru, \& Ivorra, 2018; Zhang \& Li, 2012) on the FRC including many parameters over the decades. However, using recycled materials in FRC have also been popular including steel wires extracted from waste tires. Using waste steel wires in concrete as a reinforcing matrix is not only economic but also environmental friendly.

In the last two decades utilization of recycled steel mainly from waste tires has gone up. Wang, Hu (2000) not only studied the mechanical properties of concrete by using carpet fibers, feather fibers, steel shavings, wood fibers but also waste steel wires. It is outlined that, different forms of fibers recycled from different waste materials is proper for using in concrete as a reinforcement material. However, it is reported by the researchers that increasing the dosage of waste steel wires in concrete reducing the workability (Baricevic, Bjegovic, \& Skazlic, 2017; Hu et al., 2018; M. A. Köroğlu, 2016; Leone, Centonze, Colonna, Micelli, \& Aiello, 2018; Onuaguluchi et al., 2017). Therefore, self-compacting concrete (SCC) has been widely used in order to enhance the reduction of workability in FRC which is a handicap for concrete casting on-site. Experimental researches have proved that fiber addition to concrete significantly improves some structural properties of concrete such as flexural strength, compressive strength, tensile strength, impact strength, toughness and 
ductility (Cao, Gao, Gao, \& Jia, 2018; Domone, 2006; Frazão, Camões, Barros, \& Gonçalves, 2015). However, in order to achieve improvement of structural properties the voids in concrete should be eliminated and all reinforcement must be encapsulated. Therefore, SCC and FRC not only enhance the performance the hardened concrete but also improve workability in the fresh state.

Functionally graded concrete was used in 2007 by Iskhakov and Ribakov in order to develop flexural performance of beams. Two-layer concrete elements one of which was high strength concrete used in compressive zone and normal strength concrete used in tensile zone was studied under static loading (Iskhakov \& Ribakov, 2007). Shen, Hubler, Paulino \& Struble (2008) had improved functionally-graded fiber-reinforced cement composite using four layers. Volume fractions of fibers were increased linearly from compression zone to tensile zone starting from $0 \%$ to $2 \%$. In order to maintain homogeneous layers, fiber-reinforced cement composite was pressurized gradually. When the highest fiber volume fraction was used in compression zone, developed characteristics of layered concrete was obtained (Shen, Hubler, Paulino, \& Struble, 2008). Ghasemi Naghibdehi, Naghipour \& Rabiee not only investigated the effect of crosssection reinforcement with steel fibers but also studied polypropylene with two layers under static loading (Naghibdehi, Mastali, Sharbatdar, \& Naghibdehi, 2014). Additionally, Ghasemi Naghibdehi et al. (2015) studied the mechanical properties of fiber reinforced concrete under compression, splitting tensile, and shear loads.

Then after behavior of functionally graded reinforced concrete beams were investigated under cyclic loading considering different fiber fractions (Ghasemi Naghibdehi, Naghipour, \& Rabiee, 2015).It is mentioned by the researchers that steel fiber using in concrete increases the compressive strength and the flexural strength (Iskhakov \& Ribakov, 2007; Köroğlu, 2018).

In this study, 1, 2, 3, 4 and 5\% volume fractions of waste steel fibers in concrete mix were studied firstly. Slump flow test was carried out in fresh state of concrete and compression, splitting tensile, 4 point bending tests were applied in hardened state. In the second step, different formations of layered beams containing various fiber content and height were tested. And also, SEM images were used to maintain the failure mechanisms between steel fibers and concrete matrix.

Materials and methods

\section{Materials}

\section{Recycled steel fibers from waste tires}

In this study, recycled steel fibers are recovered by a shredding process in Konya/Turkey by a recycling licensed company. The received recycled steel fibers are characterized by a nun-uniform shape and extremely variable lengths and diameters (Figure 1). Before using in concrete rubber particles in fibers were separated manually. 900 fibers extracted randomly were measured in order to obtain the geometric characterization. Fiber diameter was measured by a micrometer and varied between 0.15 and $1.8 \mathrm{~mm}$. However largest number of diameter values which is $78 \%$ of cumulative sample are cumulated between 0.22-0.27 mm as shown in Figure 2.

Figure 1. Recycled steel fibers maintained from waste tires. Source: Self Elaboration
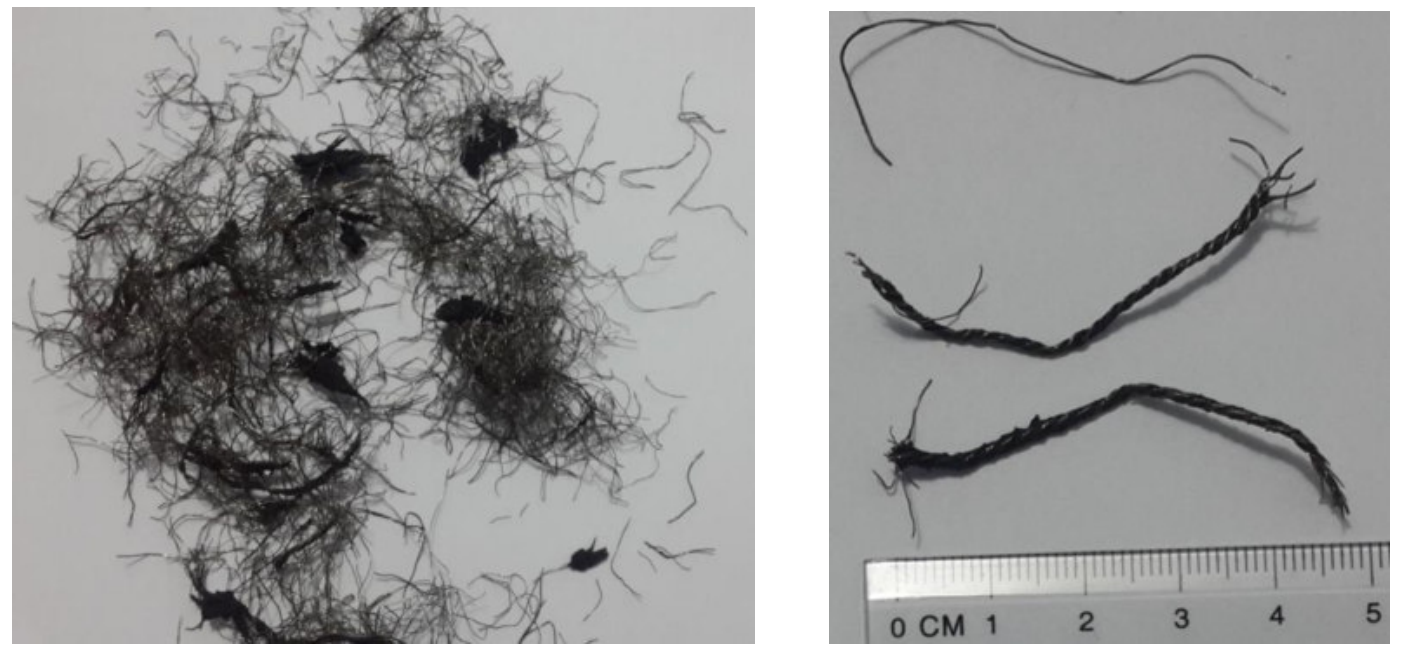


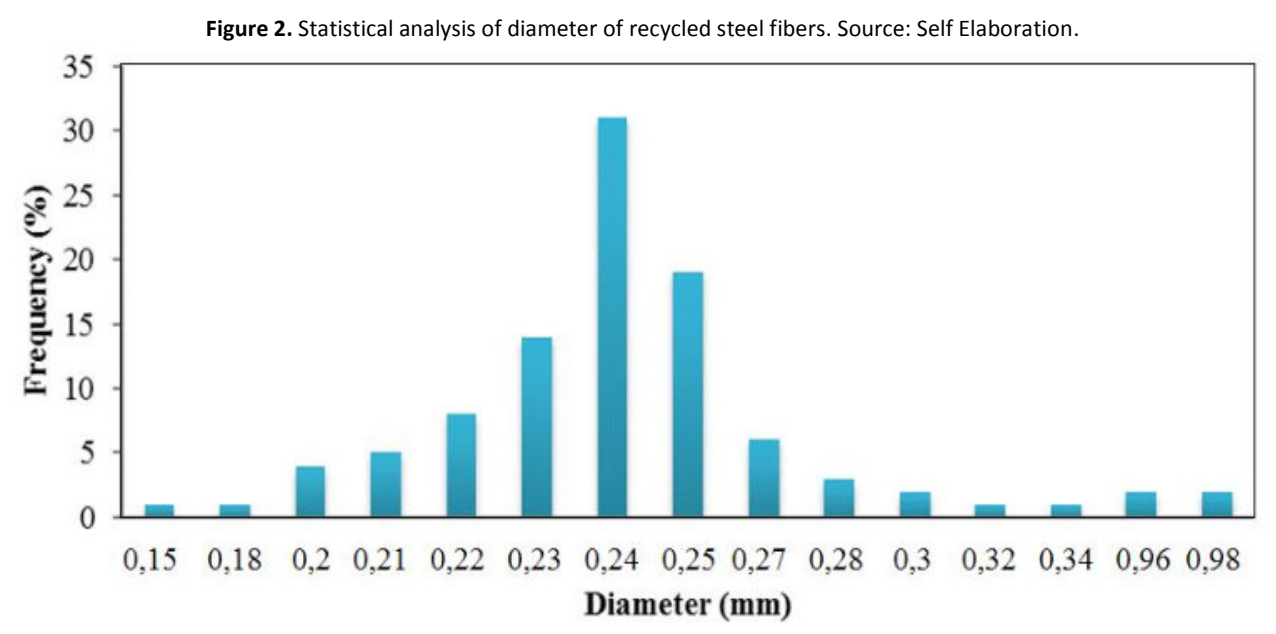

The length of the fibers was measured between outer ends of each fiber by caliper. In Figure 3 it is reported that, frequency distribution of the measured fiber length is characterized by an average distribution between $30 \mathrm{~mm}$ to 60 $\mathrm{mm}$. The total amount of cumulated fibers between $30 \mathrm{~mm}$ to $60 \mathrm{~mm}$ is $67 \%$.

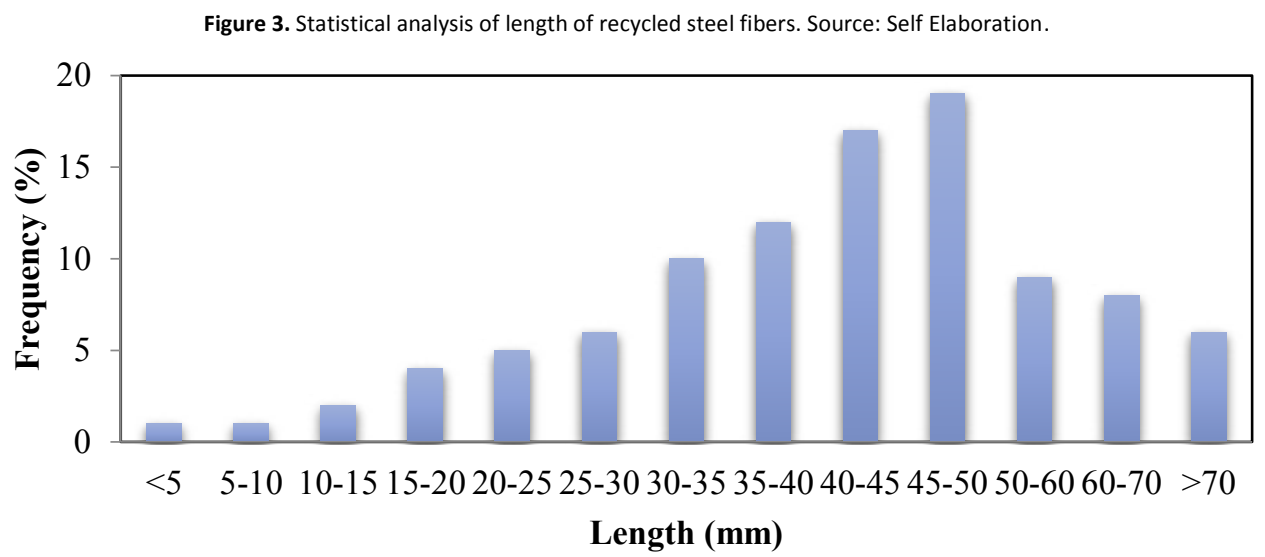

Direct tensile tests were carried out at the Structural Mechanics Laboratory of Necmettin Erbakan University and Scanning Electron Microscope (SEM) test were carried out in the Central Engineering Laboratory of Necmettin Erbakan University. Tensile tests were carried out by an electromechanical dynamometer Instron machine under displacement control. 3 specimens were chosen randomly and aluminum tabs were used to attach the fiber at each ends. The average values of 3 specimens were obtained $2134 \mathrm{MPa}$.

Recycled steel fibers were analyzed by SEM with a HITACHI SU1510 Scanning Electronic Microscope. Before Image acquisition fiber were cleaned and gold sputter coating applied under vacuum on the surface of the fibers. SEM analysis of recycled steel fiber is given in Figure 4.

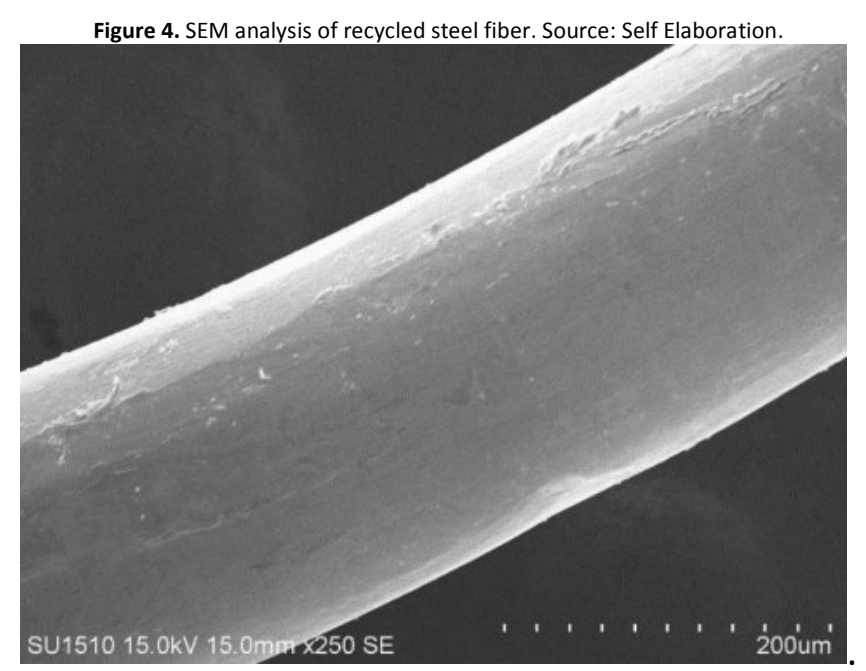


Map sum spectrum result of the recycled steel fiber is given in Figure 5 and Table 1.
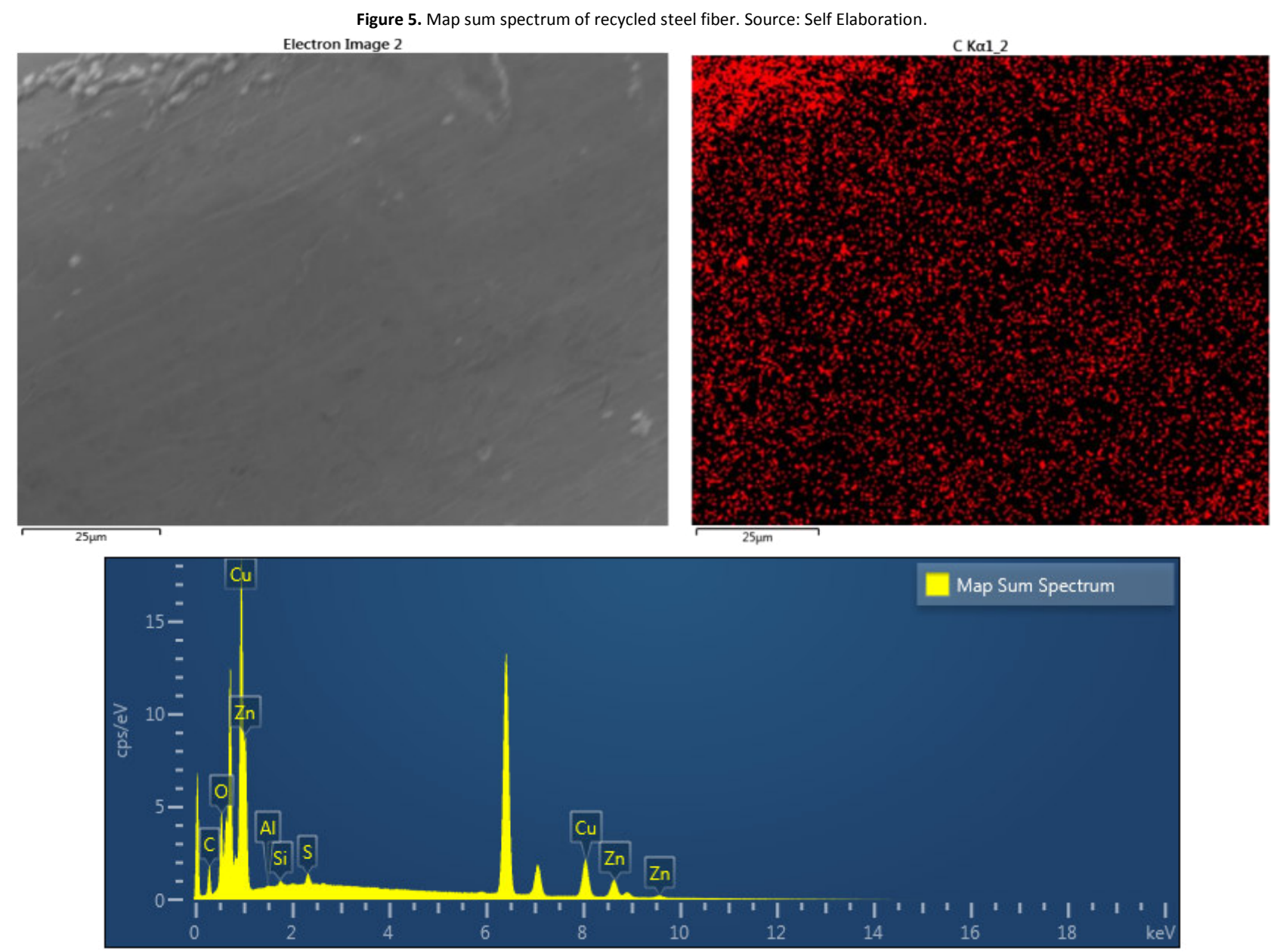

\begin{tabular}{lcccc}
\multicolumn{5}{c}{ Table 1. Map sum spectrum of recycled steel fiber. Source: Self Elaboration. } \\
\hline $\begin{array}{l}\text { Map Sum Spectrum } \\
\text { Element }\end{array}$ & Line Type & Weight \% & Weight \% Sigma & Atomic \% \\
\hline ( C ) & K series & 4.80 & 0.10 & 18.45 \\
( O ) & K series & 3.70 & 0.05 & 10.68 \\
( Fe ) & K series & 43.25 & 0.14 & 35.73 \\
( Cu ) & L series & 31.33 & 0.15 & 22.75 \\
( Zn ) & L series & 16.34 & 0.14 & 11.53 \\
(S) & K series & 0.37 & 0.02 & 0.54 \\
(Si ) & K series & 0.14 & 0.01 & 0.23 \\
( Al ) & K series & 0.06 & 0.02 & 0.10 \\
Total & & 100.00 & & 100.00 \\
\hline
\end{tabular}

\section{Cement}

CEM I 42,5 R Portland cement (TS EN 197-1:2012) was used for all concrete mixtures. The chemical compositions and physical properties of cement are given in Table 2.

\section{Aggregate}

In this study crushed limestone was used as coarse and fine aggregates with the maximum size of $8 \mathrm{~mm}$. The crushed sand was used as fine aggregate and dry specific gravity of the fine aggregate is $2.64 \mathrm{~g} / \mathrm{cm}^{3}$ and saturated specific gravity of the fine aggregate is $2.75 \mathrm{~g} / \mathrm{cm}^{3}$. Dry specific gravity of the coarse aggregate is $2.61 \mathrm{~g} / \mathrm{cm}^{3}$ and saturated specific gravity of the coarse aggregate is $2.63 \mathrm{~g} / \mathrm{cm}^{3}$. Water absorption content of coarse aggregate is $0.9 \%$ and fine aggregate is $2.1 \%$. 
Table 2. Chemical Properties of CEM I 42,5 R Portland cement. Source: Self Elaboration.

\begin{tabular}{|c|c|c|c|c|c|c|c|c|}
\hline \multicolumn{9}{|c|}{ Chemical composition (\%) } \\
\hline SiO2 & $\mathrm{Al} 2 \mathrm{O3}$ & $\mathrm{Fe} 2 \mathrm{O3}$ & $\mathrm{CaO}$ & $\mathrm{MgO}$ & $\mathrm{Na} 2 \mathrm{O}$ & $\mathrm{K} 2 \mathrm{O}$ & $\mathrm{SO} 3$ & $\mathrm{Cl}$ \\
\hline 19.70 & 4.97 & 3.58 & 64.25 & 0.91 & 0.17 & 0.77 & 2.65 & 0.011 \\
\hline \multicolumn{9}{|c|}{ Physical properties } \\
\hline \multicolumn{3}{|c|}{ Specific gravity $\left(\mathrm{g} / \mathrm{cm}^{3}\right)$} & 3.15 & & & & & \\
\hline \multicolumn{3}{|c|}{ Specific surface $\left(\mathrm{cm}^{2} / \mathrm{g}\right)$} & 3000 & & & & & \\
\hline \multicolumn{3}{|c|}{ Initial Setting time (min) } & $135-205$ & & & & & \\
\hline \multicolumn{3}{|c|}{ Blaine $\left(\mathrm{cm}^{2} / \mathrm{g}\right)$} & 3600 & & & & & \\
\hline
\end{tabular}

\section{Concrete Mix Design}

CEM I 42,5 R Portland cement with fine aggregate (0-4 mm) and course aggregate (4-8), water, steel fibers and modified polycarboxylates based polymer plasticizer admixture were added in to self-compacting concrete (SCC). In order to achieve a successful rheology of fresh concrete, fibers were mixed slowly and uniformly before water addition. The mix design is calculated based on the guidelines given in Turkish standard specification (Enstitüsü, 2009). The recycled steel fibers maintained from waste tires were supplemented at various volume fractions in concrete. Volume fractions of steel fibers in concrete mix were 1, 2, 3, 4 and 5\%. The produced mix proportion of reference concrete without any recycled steel fiber is given in Table 3. And the graded concrete beam details are presented in Table 4. In order to determine mechanical properties of hardened concrete 54 cubic specimens (100x100x100 mm), 6 cylindrical specimens $(150 \times 65 \mathrm{~mm})$ and 6 prismatic specimens $(100 \times 100 \times 400 \mathrm{~mm})$ were produced and cured in water tank up to testing.

Table 3. Concrete mix proportions. Source: Self Elaboration.

\begin{tabular}{ccccc}
\multicolumn{5}{c}{ Table 3. Concrete mix proportions. Source: Self Elaboration. } \\
\hline $\begin{array}{c}\text { Cement } \\
\left(\mathrm{kg} / \mathrm{m}^{3}\right)\end{array}$ & $\begin{array}{c}\text { Water } \\
\left(\mathrm{kg} / \mathrm{m}^{3}\right)\end{array}$ & $\begin{array}{c}\text { Coarse } \\
\text { Fine aggregate } \\
\left(\mathrm{kg} / \mathrm{m}^{3}\right)\end{array}$ & $\begin{array}{c}\text { Aggregate } \\
\left(\mathrm{kg} / \mathrm{m}^{3}\right)\end{array}$ & $\begin{array}{c}\text { Super plasticizer } \\
\left(\mathrm{kg} / \mathrm{m}^{3}\right)\end{array}$ \\
\hline 480 & 200 & 1396 & 404 & 32 \\
\hline
\end{tabular}

\begin{tabular}{|c|c|c|c|}
\hline Specimen & Fiber (\%) & $\begin{array}{c}\text { Drawing of } \\
\text { layers }\end{array}$ & $\begin{array}{c}\text { Photos of } \\
\text { layers }\end{array}$ \\
\hline Reference & 0 & & \\
\hline $3-K-1$ & 1 & . . . . . & \\
\hline $6-K-1$ & 1 & $\ldots$ & \\
\hline $3-K-2$ & 2 & $\cdots$ & \\
\hline $6-K-2$ & 2 & & \\
\hline $3-K-3$ & 3 & & \\
\hline
\end{tabular}




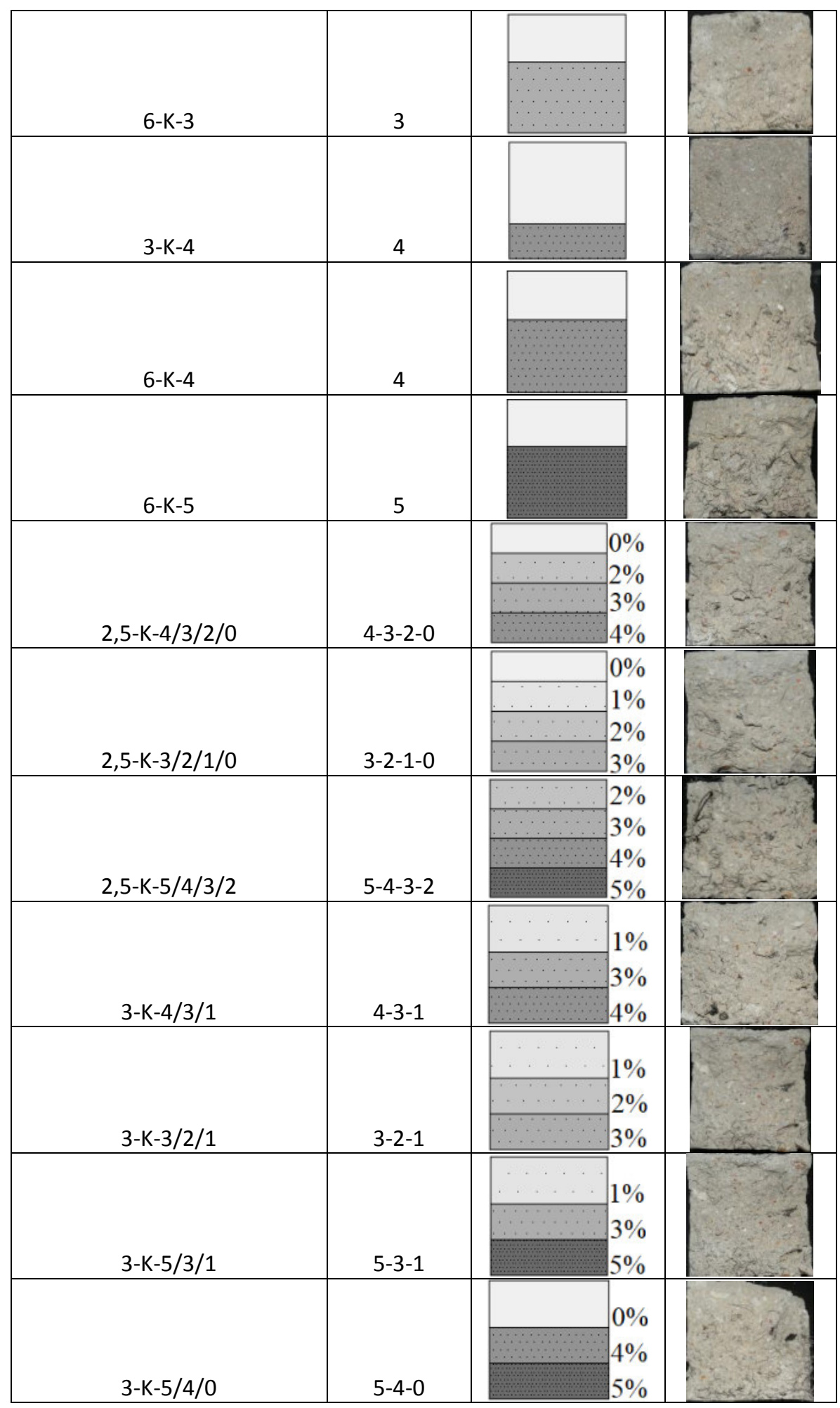

Slump flow test was carried out based on BS-EN 12350-5 (Poon, Shui, Lam, \& Research, 2004) in order to estimate the fresh-state of concrete mixture. It is well known that fiber usage in concrete matrix will definitely reduce the workability of fresh concrete. Spread diameter of fresh fiber reinforced concrete measured from slump flow tests are given in Table 5. 


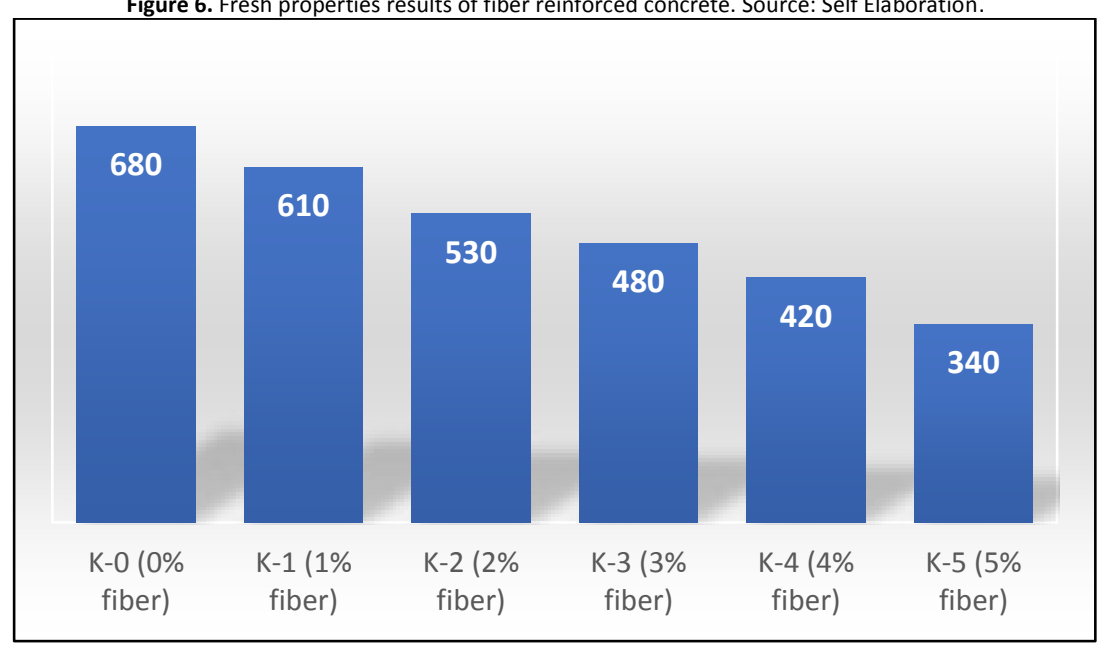

\section{Hardened Concrete Properties}

After 28 days curing in water uniaxial compression test was performed on $100 \times 100 \mathrm{~mm}$ cube hardened concrete specimens based on BS 1881-127:1990 under a loading rate of $0.3 \mathrm{MPa} / \mathrm{s}$ to investigate the compressive strength. In order to obtain the tensile strength of hardened concrete splitting tensile tests were carried out on the $100 \times 200 \mathrm{~mm}$ cylinder specimens based on ASTM C496/C496M-04 with the applied force rate equal to 0.016 MPa/s (Testing, Concrete, \& Aggregates, 2011). Additionally, flexural strength tests were utilized for each concrete with different fiber content using 100x100x500 mm beams under four point loading based on ATSM C1609/C1609M -10 (ASTM).

For all fiber reinforced concrete composition three specimens were tested for each uniaxial compression tests, splitting tensile tests and 4 point flexural strength tests, and average of the 28 days test results are reported in Table 5.

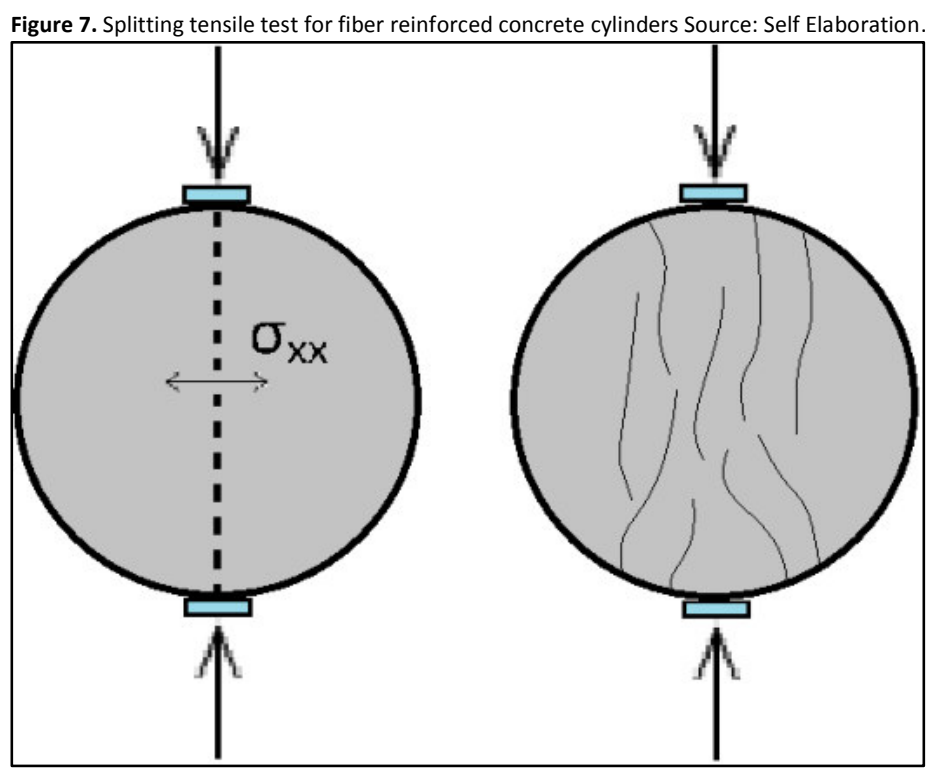

The concrete mixtures reported in the former sections were designed and prepared by using the same material content. Beam specimens of $100 \times 100 \times 400 \mathrm{~mm}^{3}$ were cast in steel molds and rodded. The test setup for performing the four point bending test and schematic figures of reinforced concrete beam details are presented in Figure 7. Force was loaded symmetrically where the span length is $300 \mathrm{~mm}$. 
Figure 8. Test setup for performing the four point bending test and schematic figures of reinforced concrete beam details. Source: Self Elaboration.

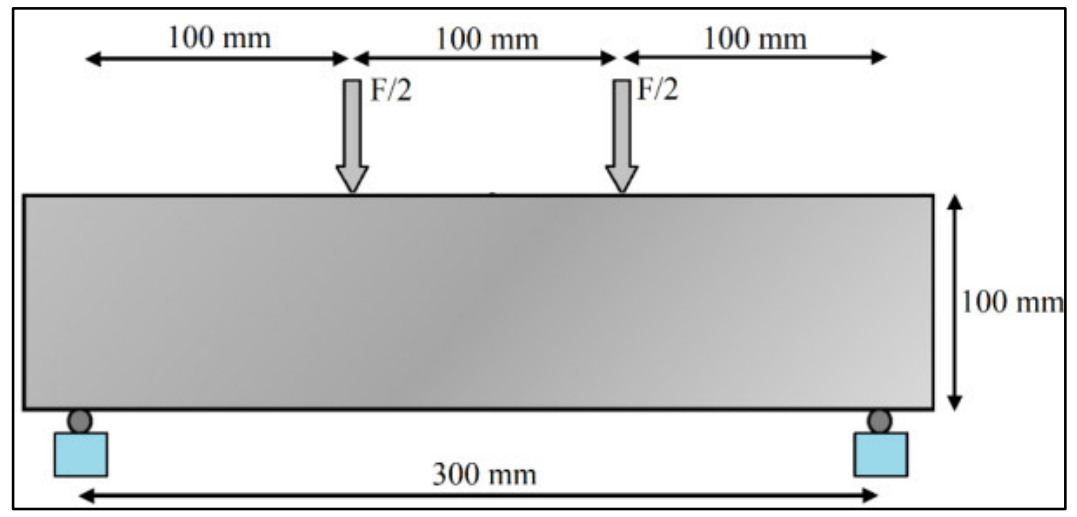

The results obtained from compressive strength, splitting tensile strength and flexural strength test are reported in Table 5.

Table 5. Mechanical properties of hardened concrete mixture. Source: Self Elaboration.

\begin{tabular}{cccc}
\multicolumn{4}{c}{ Table 5. Mechanical properties of hardened concrete mixture. Source: Self Elaboration. } \\
\hline Concrete Type & $\begin{array}{c}\sigma_{c}(M P a) \\
\text { Compressive } \\
\text { Strength }\end{array}$ & $\begin{array}{c}\sigma_{t s}(M P a) \\
\text { Splitting Tensile } \\
\text { Strength }\end{array}$ & $\begin{array}{c}\sigma_{t p}(M P a) \\
\text { Bending Tensile } \\
\text { Strength }\end{array}$ \\
\hline K-0 (0\% fiber) & 36.46 & 2.71 & 2.10 \\
K-1 (1\% fiber) & 36.26 & 3.14 & 3.60 \\
K-2 (2\% fiber) & 43.10 & 3.82 & 3.90 \\
K-3 (3\% fiber) & 44.20 & 4.16 & 5.40 \\
K-4 (4\% fiber) & 46.20 & 4.84 & 11.70 \\
K-5 (5\% fiber) & 43.75 & 4.86 & 11.10 \\
\hline
\end{tabular}

While using functionally graded method in the reinforcement of concrete beams, $100 \times 100 \times 400 \mathrm{~mm}^{3}$ were cast and tested under Four Point Bending Test conditions, at the displacement rate of $0.5 \mathrm{~mm} / \mathrm{min}$. The details of functionally graded reinforced concrete beams are shown in Figure 9. 25, 30 and $60 \mathrm{~mm}$ thickness of layers were used in the beams with different fiber content. While naming the specimens, the first number means the thickness of the specimen in $\mathrm{cm}$. Letter " $\mathrm{K}$ " is constant for all specimens and the second number shows the fiber volume percentage in the concrete matrix. In the two layered specimens different fiber content from $1 \%$ to $5 \%$ was used in the tension zone of the beam with the height of $30 \mathrm{~mm}$ and $60 \mathrm{~mm}$ while plain concrete is used in the rest of the specimen.

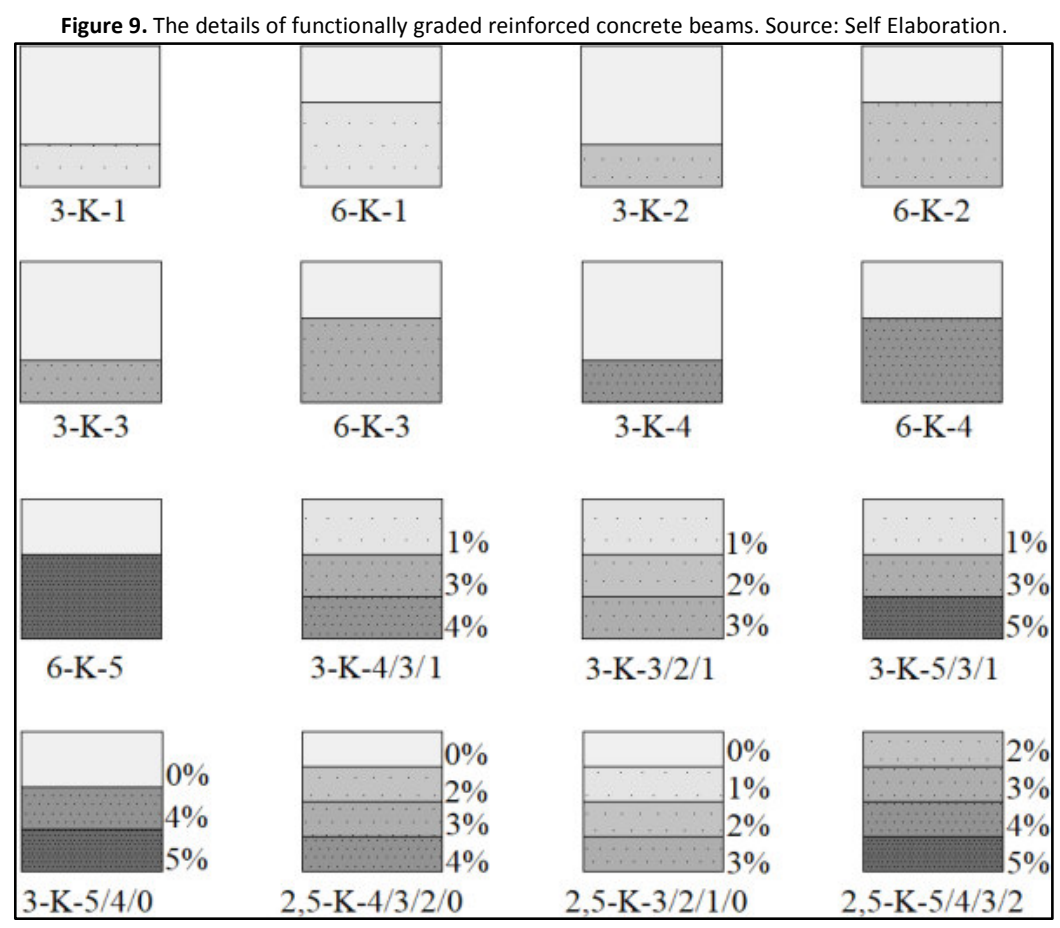


Four point bending test was used for the proposed functionally graded reinforced concrete beam and Load Displacement graphs are presented in Figures 10-13. The test results show that, steel fiber addition improves the maximum load and post-cracking properties of reinforced concrete as compared to plain concrete. Also, load bearing capacity improves parallel with the steel fiber content in the specimens with $30 \mathrm{~mm}$ height and additionally the level of improvement is more manifest in the specimens with $60 \mathrm{~mm}$ height.

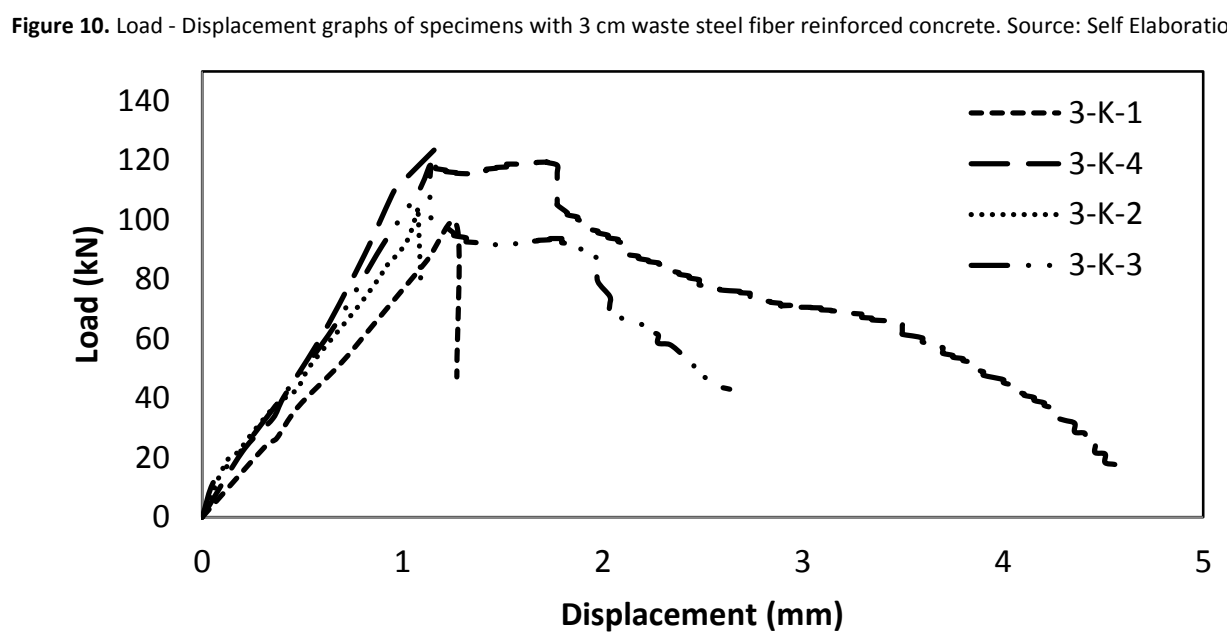

Pull-out of fibers was observed for all fiber-reinforced specimens under flexural failure. A significant improvement of toughness in the specimens with $3 \%$ and $4 \%$ fibers was determined. Also toughness of the specimens with $3 \mathrm{~cm}$ steel fiber reinforced concrete was improved, load bearing capacity was not increased significantly (Figure 11).

Figure 11. Load - Displacement graphs of specimens with $6 \mathrm{~cm}$ waste steel fiber reinforced concrete. Source: Self Elaboration.

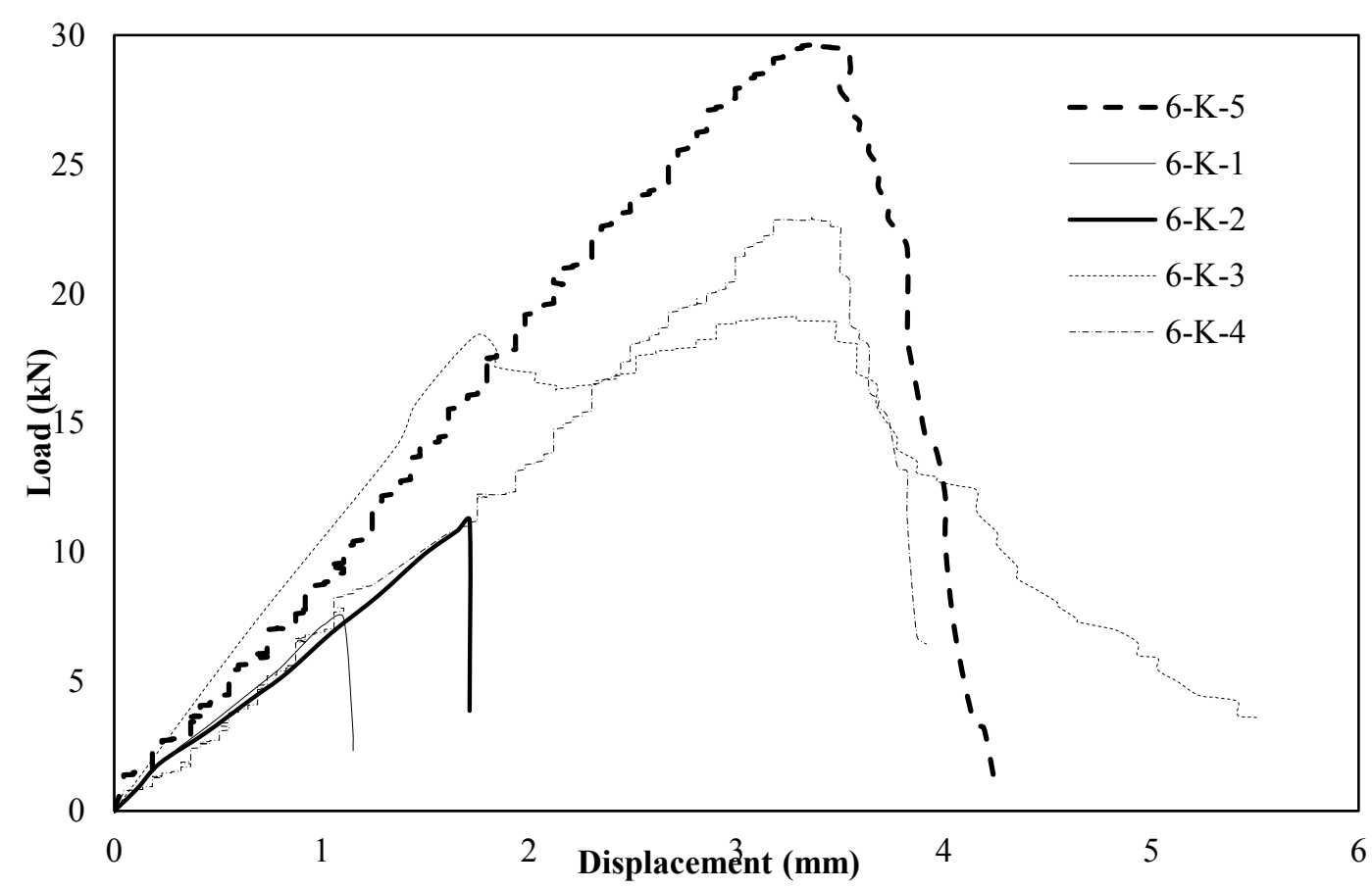

In the specimens with $6 \mathrm{~cm}$ steel fiber reinforced concrete, load bearing capacity was influenced effectively by increase of fiber content (Figure 12). Since the tensile strength of fibers is very high, pull-out of fibers was observed in all beams. Because of pull-out failures the load capacity reduced suddenly. 


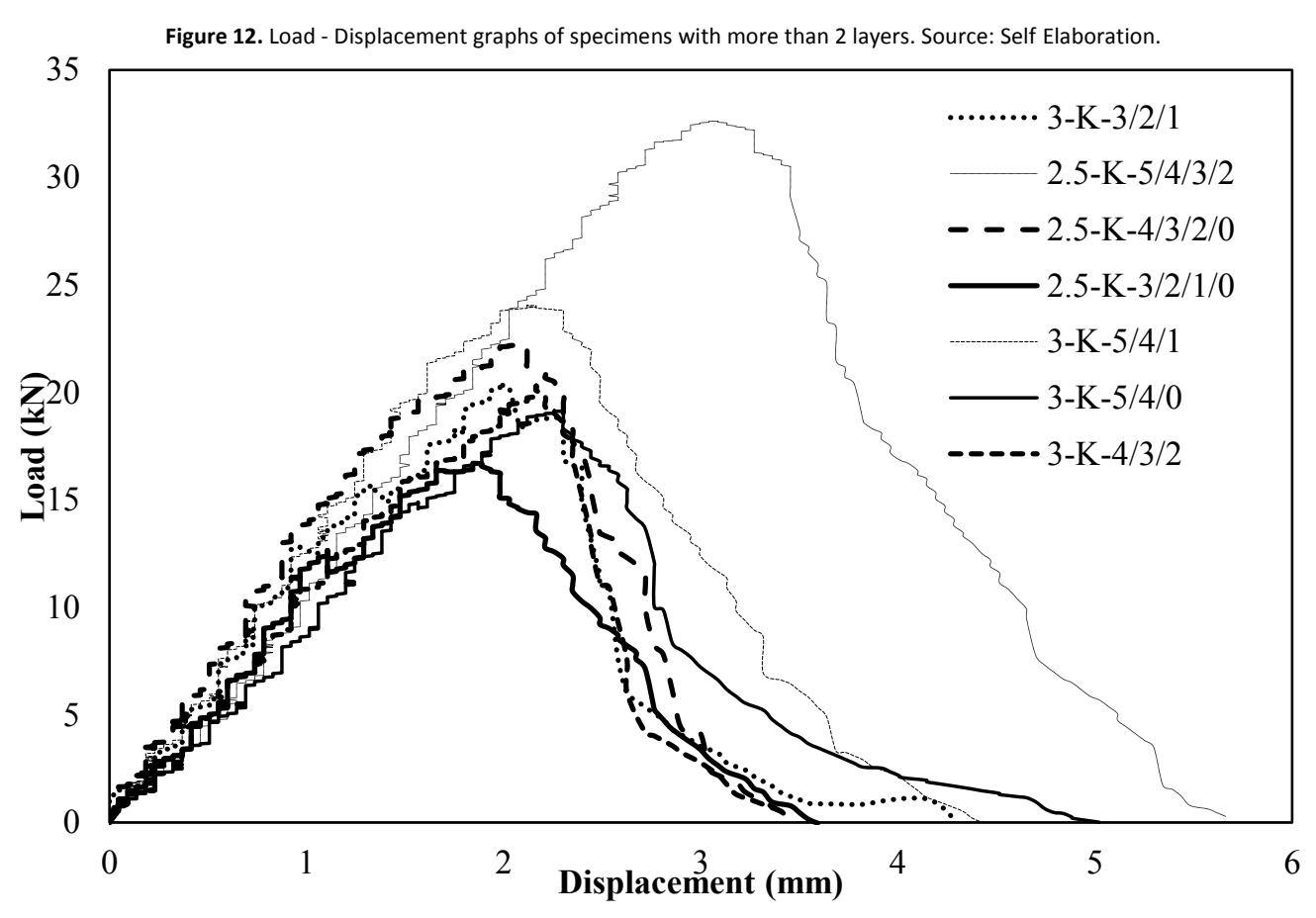

For the specimens with more than 2 layers similarly load bearing capacity was influenced effectively by increase of fiber content. It is clearly seen from Figure 13 that, increasing height of the fiber reinforced concrete influences the bending capacity of the specimens. Using steel fiber develops both tensile and compressive strength of concrete, specimens with high reinforced layer has high load bearing capacity. In Figure 13, Load - Displacement graphs of specimens with steel fiber ratios of $4 \%$ with different orientations are given. Also for the specimen $3 \mathrm{~K}-4 / 3 / 1$ has higher tension zone ( $3 \mathrm{~cm})$ with the same steel fiber content (4\%) compared to $2.5 \mathrm{~K}-4 / 3 / 2 / 1(2.5 \mathrm{~cm})$, specimen $2.5 \mathrm{~K}-4 / 3 / 2 / 1$ has higher load capacity compared to the specimen $3 \mathrm{~K}-4 / 3 / 1$.

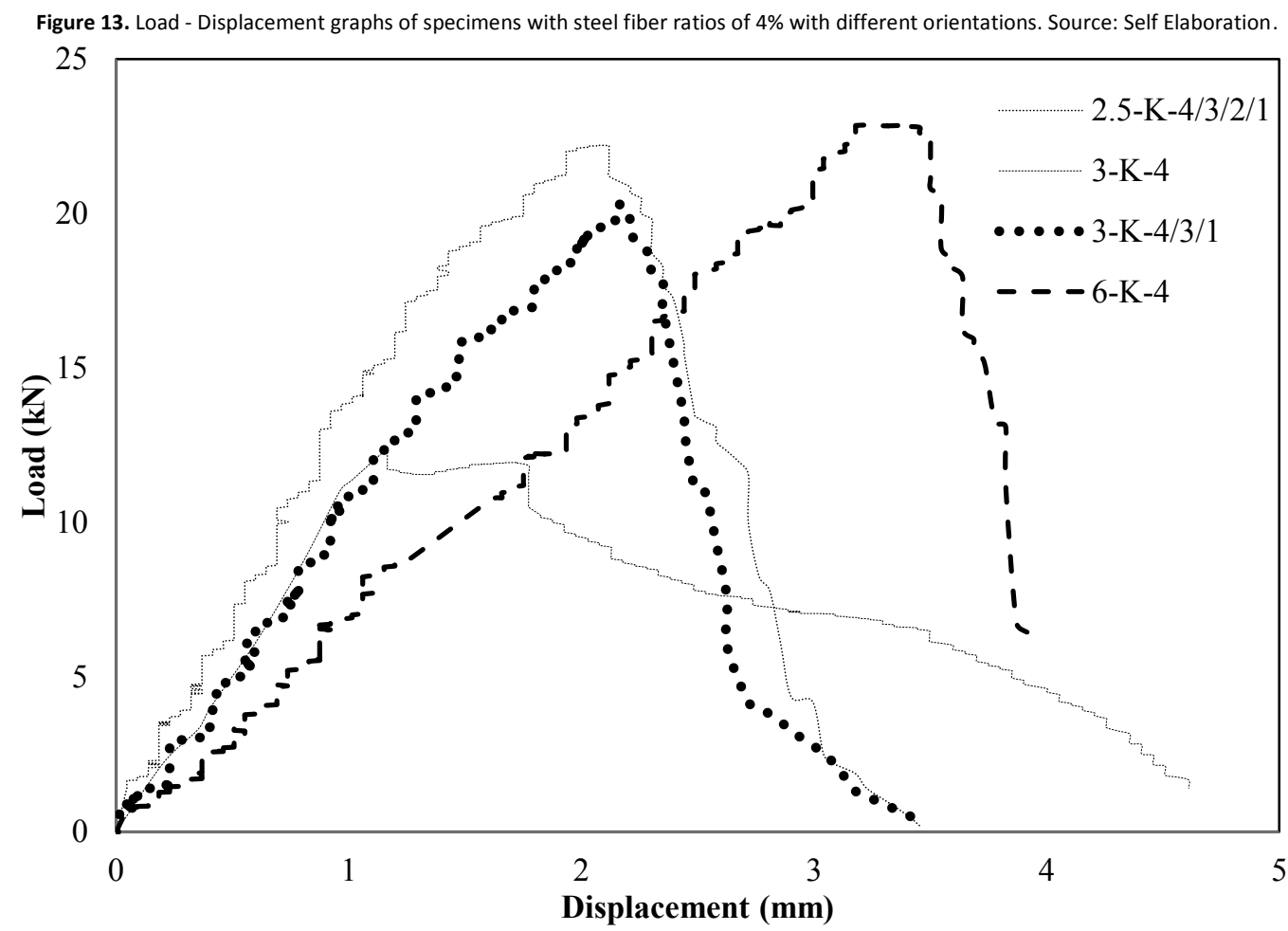

Micro-cracks was observed during 4 point loading test in tensile region of the beams when the tensile strength of concrete matrix was reached. Steel fibers balanced the crack bridging until the maximum load. Steel fiber addition and height of fibered concrete influenced the crack development. When maximum load was applied to beam, fibers started pulling out from the concrete matrix. When the first pull-out failure was developed, a sudden failure was observed. This 
sudden failure was affected by the rigidity of the layers. When the layers changed, crack orientation also changed. In Figure 14 the horizontal crack is clearly seen on the specimen $3-K-5 / 4 / 0$.

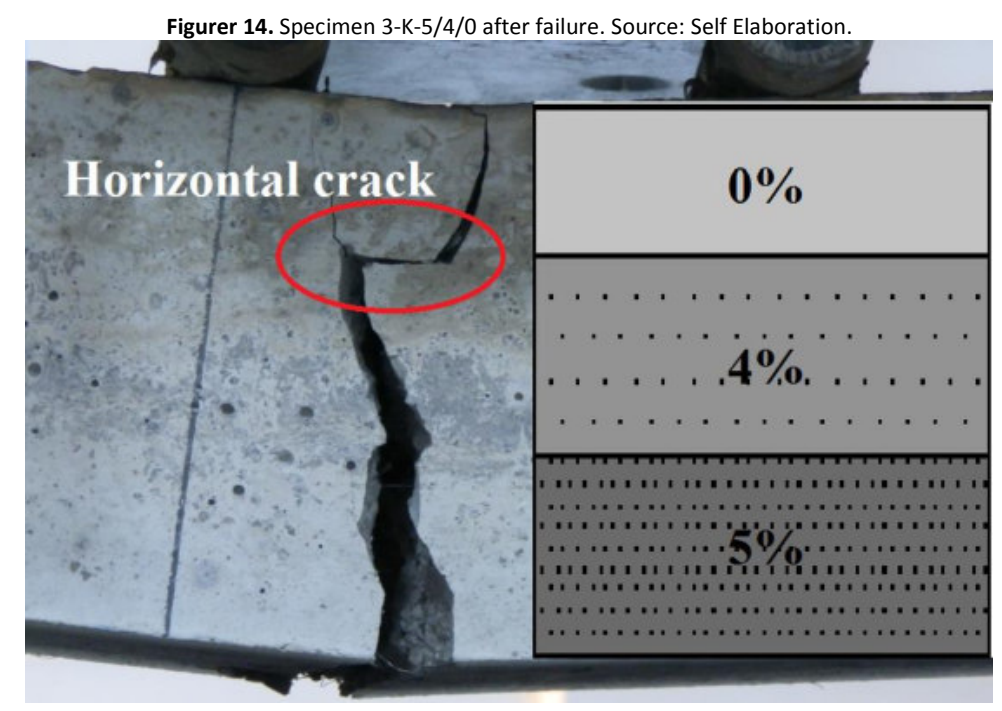

\section{Microstructure test}

SEM images were used to maintain the failure mechanisms between steel fibers and concrete matrix. SEM images of the concrete containing $4 \%$ waste tire steel fiber for $0.417 \mathrm{w} / \mathrm{c}$ ratio specimens are given in Figure (a), (b), (c), (d), (e) and (f). Various micro cavities containing water gaps are observed in the concrete matrix as shown in Figure 14(a) and (e) that increase the strength of concrete. Interface between waste rubber and concrete is observed in Figure 13 (b) where a poor bond between rubber particles and concrete matrix. And also SEM images indicate that the rubber particles in concrete have asymmetrical structure. In Figure 15 (c) and (d) it thin rubber cover on steel wire is observed. This thin cover maintains a gap at the interface of steel and concrete matrix. Cracking at the interface between the rubber and concrete shows that the bonding will be poor if rubber particles covers the steel wires. Therefore, reducing of the concrete strength may be because of the cracks at the interface.

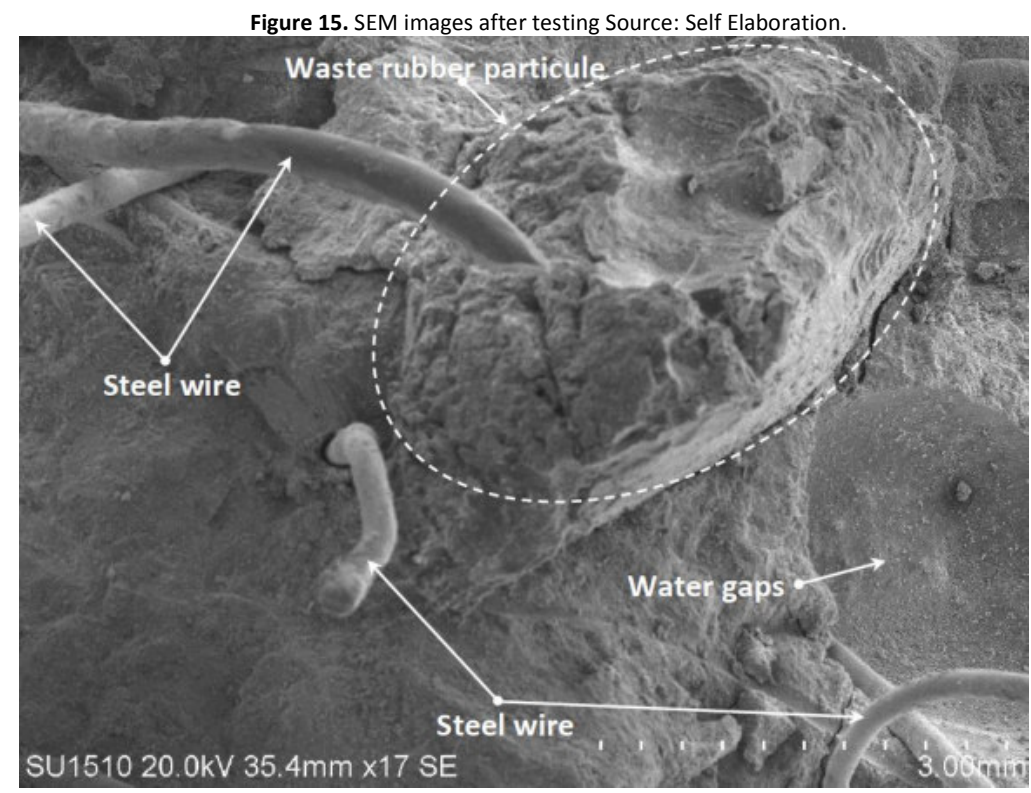

(a) 


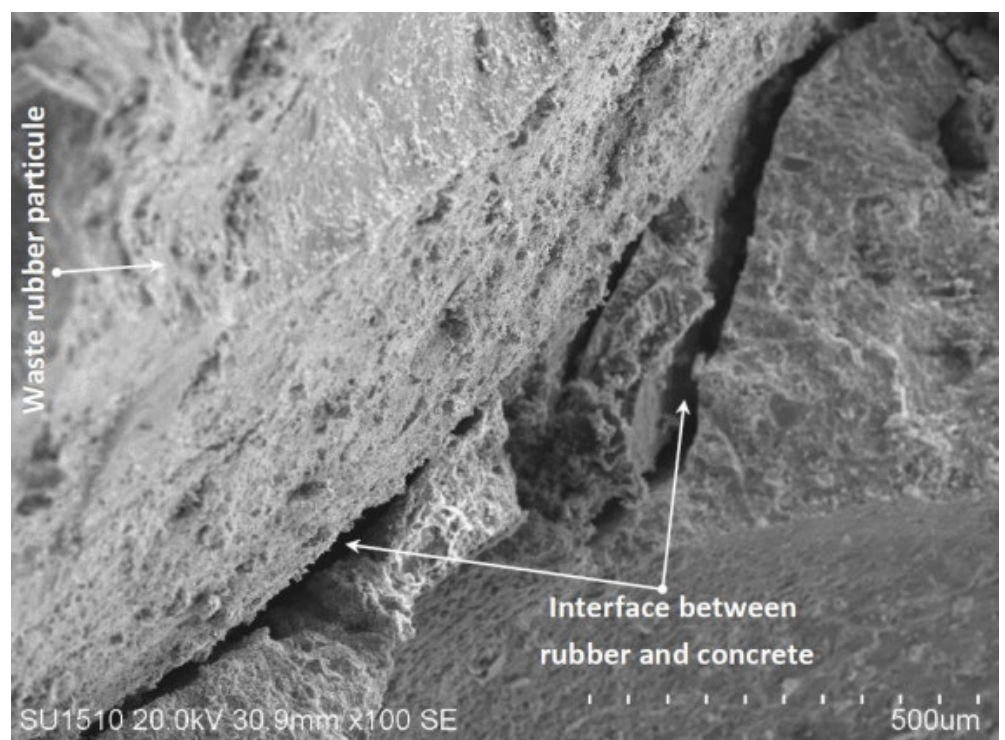

(b)

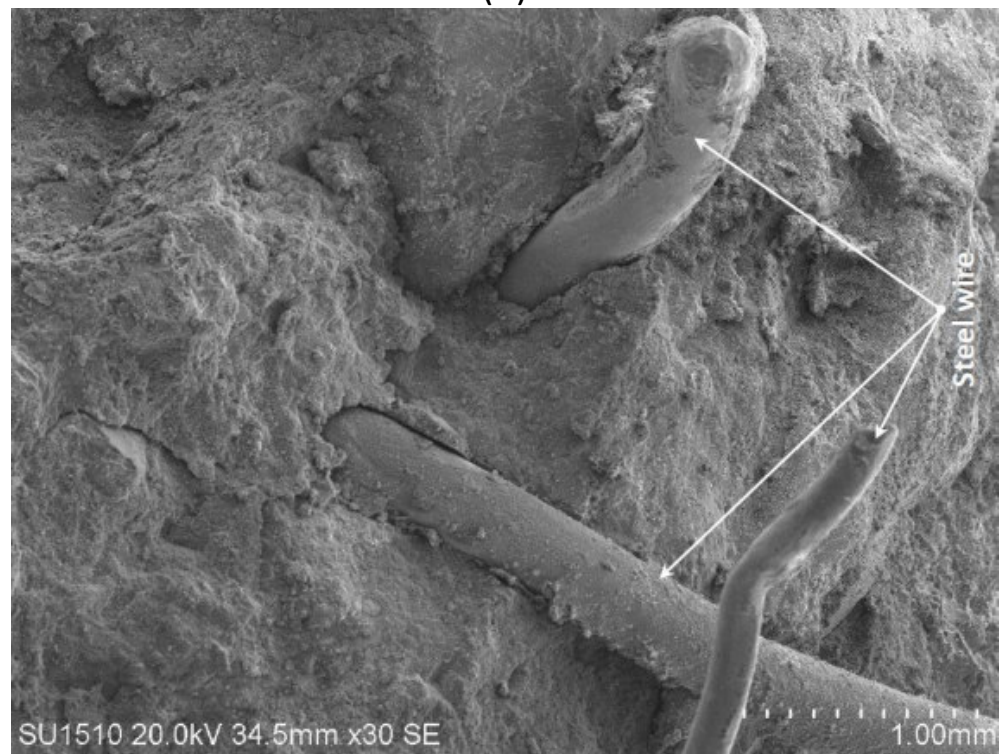

(c)

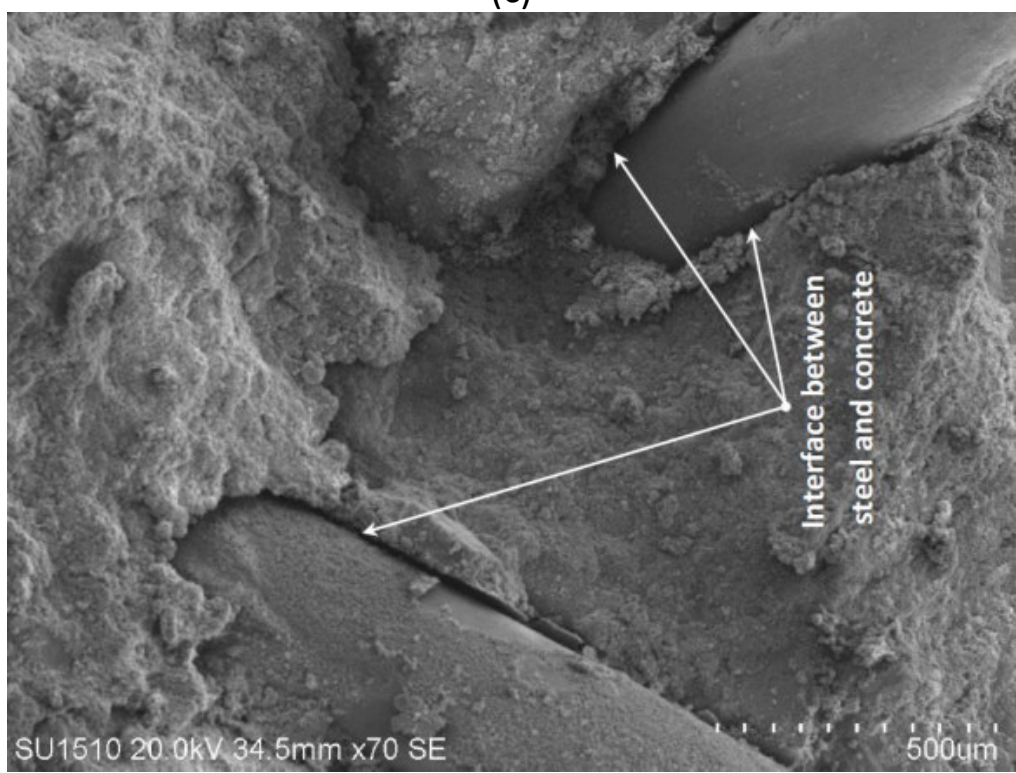

(d) 


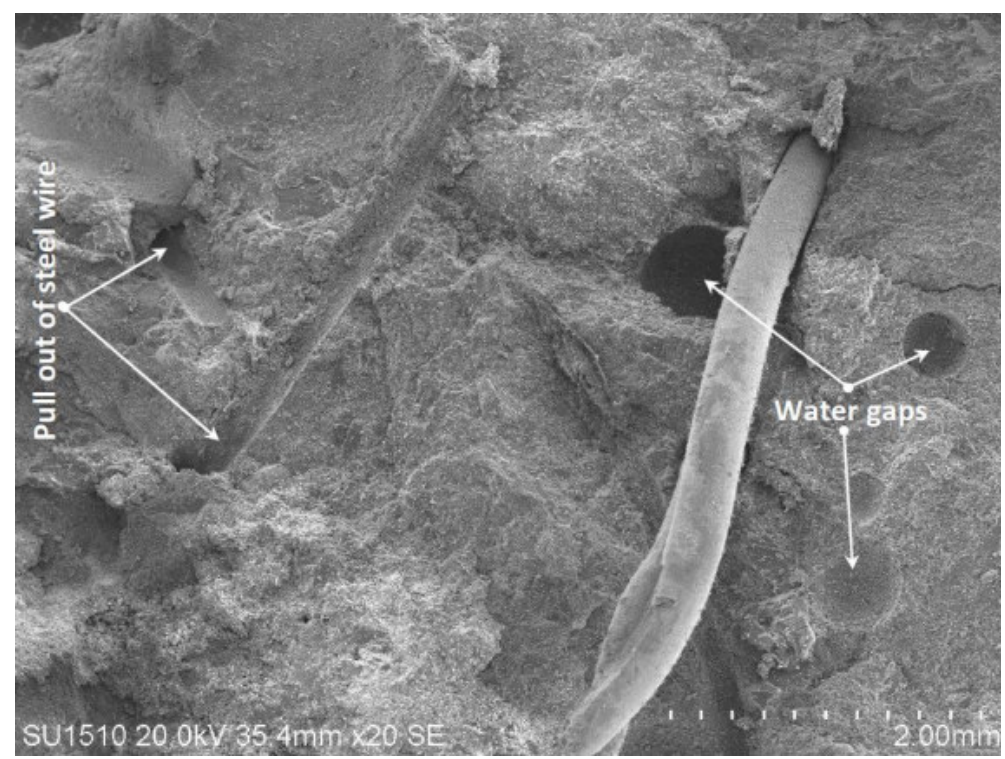

(e)

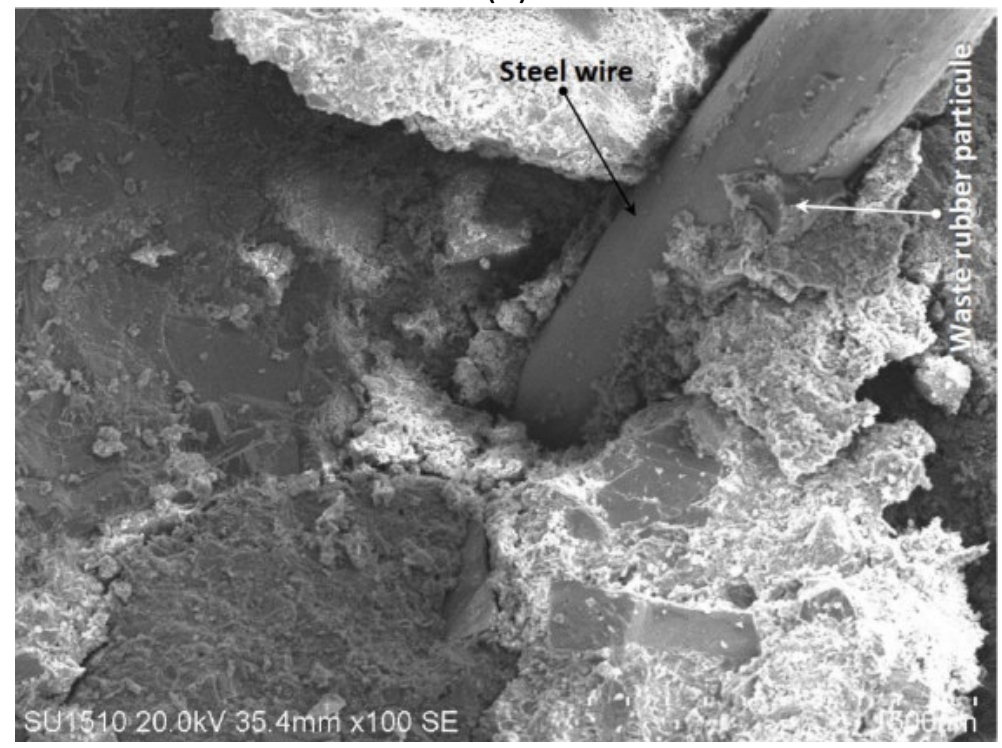

(f)

As expected, using fibers in SCC beams improved both tensile and residual strength or softening behavior of waste steel fiber reinforced SCC concrete. According to the experimental results, the following results were concluded.

- Workability of fresh concrete was decreased with the increase in the volume fraction of fiber. However, workability was improved with a polycarboxylates based polymer plasticizer admixture that also provided more uniform fiber distribution in concrete.

- Overall strength of hardened concrete was improved by using waste steel fibers in SCC. Not only compressive strength but also splitting tensile and flexural strength was improved with the increase in the volume fraction of fiber. But the strength development of splitting tensile and flexural strength was higher compared to compressive strength.

- No sliding was observed in functionally graded waste steel reinforced SCC. Therefore, a perfect bond was established between layers with different fiber ratios.

- Functionally graded waste steel reinforced SCC has slightly different behaviour compared with the specimen with the same fiber content in the first tension zone of the beam.

- SEM images shows that, rubber particles on steel wires cause cracking at the interface that is reducing the bonding and concrete strength.

- It is understood in this study that the waste steel fiber has a good potential for concrete as a reinforcement material. However, some disadvantages like balling of fibers should be solved and long-term investigations should be studied. 
Amin, A., Foster, S. J., Gilbert, R. I., \& Kaufmann, W. (2017). Material characterisation of macro synthetic fibre reinforced concrete. Cement and Concrete Composites, 84(Supplement C), 124-133. doi:https://doi.org/10.1016/j.cemconcomp.2017.08.018

ASTM, I. (2010). Standard test method for flexural performance of fiber-reinforced concrete (using beam with third-point loading). United States.

Baricevic, A., Bjegovic, D., \& Skazlic, M. (2017). Hybrid Fiber-Reinforced Concrete with Unsorted Recycled-Tire Steel Fibers. Journal of Materials in Civil Engineering, 29(6), 06017005.

Bharath, K. N., \& Basavarajappa, S. (2016). Applications of biocomposite materials based on natural fibers from renewable resources: a review. Science and Engineering of Composite Materials, 23(2), 123-133.

Cao, Q., Gao, Q., Gao, R., \& Jia, J. (2018). Chloride penetration resistance and frost resistance of fiber reinforced expansive self-consolidating concrete. Construction and Building Materials, 158(Supplement C), 719-727. doi:https://doi.org/10.1016/j.conbuildmat.2017.10.029

Domone, P. L. (2006). Self-compacting concrete: An analysis of 11 years of case studies. Cement and Concrete Composites, 28(2), $197-208$. doi:https://doi.org/10.1016/j.cemconcomp.2005.10.003

T. S. 802 (2009). Beton Karışım Tasarımı Hesap Esasları. TS, 802, 1-29.

Fiala, L., Toman, J., Vodička, J., \& Ráček, V. (2016). Experimental Study on Electrical Properties of Steel-fibre Reinforced Concrete. Procedia Engineering, 151, 241-248.

Frazão, C., Camões, A., Barros, J., \& Gonçalves, D. (2015). Durability of steel fiber reinforced self-compacting concrete. Construction and Building Materials, 80(Supplement C), 155-166. doi:https://doi.org/10.1016/j.conbuildmat.2015.01.061

Ghasemi Naghibdehi, M., Naghipour, M., \& Rabiee, M. (2015). Behaviour of functionally graded reinforced-concrete beams under cyclic loading. Građevinar, 67(05.), 427-439.

Holschemacher, K., Mueller, T., \& Ribakov, Y. (2010). Effect of steel fibres on mechanical properties of high-strength concrete. Materials \& Design (1980-2015), 31(5), 2604-2615. doi:https://doi.org/10.1016/j.matdes.2009.11.025

Hu, H., Papastergiou, P., Angelakopoulos, H., Guadagnini, M., Pilakoutas, K. J. C., \& Materials, B. (2018). Mechanical properties of SFRC using blended manufactured and recycled tyre steel fibres. Construction and Building Materials, 163, 376-389.

Institutions, B. S. (1881). Method for determination of compressive strength of concrete cubes. London BS.

Iskhakov, I., \& Ribakov, Y. (2007). A design method for two-layer beams consisting of normal and fibered high strength concrete. Materials \& Design, 28(5), 1672-1677. doi:https://doi.org/10.1016/j.matdes.2006.03.017

Köken, A., Köroğlu, M. A., \& Yonar, F. (2008). Atık betonların beton agregası olarak kullanılabilirliği. Selcuk-Teknik Online Dergisi, 7(1), 86-97

Köksal, F., Gencel, O., Unal, B., \& Durgun Muhammed, Y. (2012). Durability properties of concrete reinforced with steel-polypropylene hybrid fibers. Science and Engineering of Composite Materials, 19, pp. 19).

Köroğlu, M. A. (2016). Mechanical characterization of recycled tires in concrete. Selcuk University Journal of Engineering, Science and Technology, $4(4), 330-336$.

Köroglu, M. A., \& Özdöner, N. J. K. E. M. (2016). Behavioural Study of Steel Fiber and Polypropylene Fibre Reinforced Concrete. Key Engineering Materials, 708, 59.

Köroğlu, M. A. (2018). Artificial neural network for predicting the flexural bond strength of FRP bars in concrete. Science and Engineering of Composite Materials. DOI: https://doi.org/10.1515/secm-2017-0155

Lee, J., Yi, C., \& Oh, Y. (2008). Strengthening of Concrete with Mixed Confinement Materials - Steel Hoops and FRP Composites. Science and Engineering of Composite Materials, 15, 1-19.

Leone, M., Centonze, G., Colonna, D., Micelli, F., \& Aiello, M. (2018). Fiber-reinforced concrete with low content of recycled steel fiber: Shear behaviour. Construction and Building Materials, 161, 141-155.

Lerch, J., Bester, H., Van Rooyen, A., Combrinck, R., de Villiers, W., Boshoff, W. J. C., \& Research, C. (2018). The effect of mixing on the performance of macro synthetic fibre reinforced concrete. Cement and Concrete Research, 103, 130-139.

Lerch, J. O., Bester, H. L., Van Rooyen, A. S., Combrinck, R., de Villiers, W. I., \& Boshoff, W. P. (2018). The effect of mixing on the performance of macro synthetic fibre reinforced concrete. Cement and Concrete Research, 103(Supplement C), 130-139. doi:https://doi.org/10.1016/j.cemconres.2017.10.010

Li, Z.-X., Li, C.-H., Shi, Y.-D., \& Zhou, X.-J. (2017). Experimental investigation on mechanical properties of Hybrid Fibre Reinforced Concrete. Construction and Building Materials, 157(Supplement C), 930-942. doi:https://doi.org/10.1016/j.conbuildmat.2017.09.098

Liu, K., Lu, L., Wang, F., \& Liang, W. (2017). Theoretical and experimental study on multi-phase model of thermal conductivity for fiber reinforced concrete. Construction and Building Materials, 148(Supplement C), 465-475. doi:https://doi.org/10.1016/j.conbuildmat.2017.05.043

Macanovskis, A., Krasnikovs, A., Kononova, O., \& Lukasenoks, A. (2017). Mechanical Behavior of Polymeric Synthetic Fiber in the Concrete. Procedia Engineering, 172(Supplement C), 673-680. doi:https://doi.org/10.1016/j.proeng.2017.02.079

Naghibdehi, M. G., Mastali, M., Sharbatdar, M. K., \& Naghibdehi, M. G. J. M. o. C. R. (2014). Flexural performance of functionally graded RC crosssection with steel and PP fibres. Magazine of Concrete Research, 66(5), 219-233. 
Olivito, R. S., \& Zuccarello, F. A. (2010). An experimental study on the tensile strength of steel fiber reinforced concrete. Composites Part B: Engineering, 41(3), 246-255. doi:https://doi.org/10.1016/j.compositesb.2009.12.003

Onuaguluchi, O., Borges, P. H., Bhutta, A., \& Banthia, N. (2017). Performance of scrap tire steel fibers in OPC and alkali-activated mortars. Materials and Structures, 50(2), 157.

Poon, C., Shui, Z., Lam, L. J. C., \& Research, C. (2004). Compressive behavior of fiber reinforced high-performance concrete subjected to elevated temperatures. Cement and Concrete Research, 34(12), 2215-2222.

Poon, C. S., Shui, Z. H., \& Lam, L. (2004). Compressive behavior of fiber reinforced high-performance concrete subjected to elevated temperatures. Cement and Concrete Research, 34(12), 2215-2222. doi:https://doi.org/10.1016/j.cemconres.2004.02.011

Richardson, A., \& Ovington, R. (2017). Temperature related steel and synthetic fibre concrete performance. Construction and Building Materials, 153(Supplement C), 616-621. doi:https://doi.org/10.1016/j.conbuildmat.2017.07.101

Shen, B., Hubler, M., Paulino, G. H., \& Struble, L. J. (2008). Functionally-graded fiber-reinforced cement composite: Processing, microstructure, and properties. Cement and Concrete Composites, 30(8), 663-673. doi:https://doi.org/10.1016/j.cemconcomp.2008.02.002

Tassew, S. T., \& Lubell, A. S. (2014). Mechanical properties of glass fiber reinforced ceramic concrete. Construction and Building Materials, 51(Supplement C), 215-224. doi:https://doi.org/10.1016/j.conbuildmat.2013.10.046

ASTM C496: 2011. Standard test method for splitting tensile strength of cylindrical concrete specimens. Available https://www.astm.org/Standards/C496.htm

Varona, F. B., Baeza, F. J., Bru, D., \& Ivorra, S. (2018). Influence of high temperature on the mechanical properties of hybrid fibre reinforced normal and high strength concrete. Construction and Building Materials, 159(Supplement C), 73-82. doi:https://doi.org/10.1016/j.conbuildmat.2017.10.129

Wei, J., \& Meyer, C. (2015). Degradation mechanisms of natural fiber in the matrix of cement composites. Cement and Concrete Research, 73(Supplement C), 1-16. doi:https://doi.org/10.1016/j.cemconres.2015.02.019

Zhang, P., \& Li, Q.-f. (2012). Effect of polypropylene fiber on fracture properties of high-performance concrete composites. Science and Engineering of Composite Materials. In (Vol. 19, pp. 407). 